\title{
A Study on Customer Attitude and Satisfaction towards HP Gas Company LPG Users in Theni District
}

\author{
${ }^{1}$ M.BALA SUBBULAKSHMI, ${ }^{2}$ DR.J.MALARVIZHI \\ ${ }^{1}$ M.Phil Scholar, ${ }^{2}$ Assistant Professor, Department of Commerce, Nadar Saraswathi College of \\ Arts \& Science, Theni, India.
}

\begin{abstract}
The present scenario in LPG industry there are many opportunities for LPG to contribute to improve living standards. LPG sector is constantly facing challenges from the market. LPG is not commonly found in rural areas where biomass use tends to be highest and where the health effects of smoke are also highest. The main purpose of the study is to understand the approach and satisfaction of consumer towards sales and service of LPG agency which will help the company to make proper marketing strategy to rendered good services and satisfy the needs of the customer. Customers also have the right to select their suppliers of LPG as well as good service quality.
\end{abstract}

Keywords: LPG, customer, services, satisfaction

\section{INTRODUCTION}

Across the world, LPG industry is continuously facing strong competition all over the world. LPG sector is constantly facing challenges from the market. The main domestic uses of LPG are with respect to lighting, refrigeration, cooking and most of all heating. It also releases women and children from the drudgery of collecting firewood and health problems associated with carrying heavy bundles long distances. LPG is not commonly found in rural areas where biomass use tends to be highest and where the health effects of smoke are also highest. However, it is used amongst middle or high income groups in urban areas of developing countries. Customers also have the right to select their suppliers of LPG as well as good service quality. In today's LPG market, complains registration is done through computerised process by the customers and the customers are becoming more sensitive to LPG gas problems.

\section{OBJECTIVES OF THE STUDY}

* To study the awareness and attitude towards LPG in households.

* To analyze the demographic profile of LPG customer in Theni district.

* To evaluate the satisfaction level of respondents towards agency services.

* To identify the factors which affects improvement and development in rendering service.

* To offer valid suggestions to the HP Gas Company based on the findings.
History of the LPG

Liquefied petroleum gas or liquid petroleum gas (LPG or LP gas), is a flammable mixture of hydrocarbon gases used as fuel in heating appliances, cooking equipment, and vehicles. LPG was first said to be discovered Dr. Walter Snelling in the early part of the $20^{\text {th }}$ century. It was then, when the world was introduced to liquefied petroleum gas and it was Snelling who as a scientist discovered that some gases could be stored as liquids under moderate pressure. LPG is produced during oil refining or is extracted during the natural gas production process. If you release LPG, gas is emitted. In order to transport it, LPG needs to be placed under modest pressure to form a liquid. It can then be stores and transported in LPG cylinders.

\section{STATEMENT OF THE PROBLEM}

LPG is known to be the most suitable and effective energy substitute for domestic, as well as business, use. It is a philosophy and an attitude of professional commitment, which believes in the ultimate satisfaction or each customer 'wants'. The statement that it is offers multiuse at lower costs than other energy sources, accompanied with its environmentally-friendly nature, greatly increases the demand among people. This can occasionally make some suppliers charge more than they should. It can sometimes make some suppliers charges. The leading professionals of today have been exercising their decision making process with the ultimate the goal of satisfying the customers.

\section{SCOPE OF THE STUDY}

$\checkmark$ The study helps the researcher to have a practical exposure in this specific field. 
$\checkmark$ The study helps the HP Gas Company to know the customer's attitude and satisfaction level among their product as well as service.

$\checkmark$ The Study helps the respondents to disclose their opinion and views about the HP LPG services.

$\checkmark$ The study results will be of a great help to the government in future price policy making.

\section{REVIEW OF LITERATURE}

Purvin \& Gertz (2013) in his articles "World LPG Market Outlook" stated that, over the past several years, the international LPG industry has seen a gradual shift in world trade patterns. Demand in the East of Suez market has risen faster than LPG supplies in the region. This has reduced the need for Middle Eastern LPG producers to move LPG into Western markets and put upward pressure on Middle Eastern and Asian LPG prices.

Babasab Patil (2012), conducted a study titled, "Customer satisfaction on bharat gas agencies in Coimbatore", and he concluded that, the gas agency are well established in providing satisfactory after sales services to its customers. By seeing the observations most of the customers are having positive perception towards that particular gas agency and are satisfied with its services such as Availability of Timely and safe delivery, Staff support, Trained Mechanics etc.

\section{BENEFITS OF LPG}

$>$ LPG consists of hydrocarbons, so it burns cleanly without leaving any residue.

$>$ LPG is characterized by high thermal efficiency and heating rate.

$>$ It is easy to manipulate.

$>$ In the long run the maintenance cost is very less when compared to the present systems.

$>$ Needs little care for maintenance.

$>$ Produces smoother power with fewer emissions.

$>$ Comparatively it is less of health hazard, even in case of leakage.

$>$ It is free from CO, so it is less hazardous.

\section{USES OF LPG}

LPG has a very wide variety of uses, mainly used for cylinders across many different markets as an efficient fuel container in the agricultural, recreation, hospitality, industrial construction, sailing and fishing sectors. It can serve as fuel for cooking, central heating and to water heating and is a particularly cost-effective and efficient way to heat off-grid homes.

\section{* Cooking}

There are many types of cooking appliances that are amongst the main LPG applications. LPG is used for cooking in many countries for economic reasons, for convenience or because it is preferred fuel source. Most of the LPG requirement is imported. Increase in LPG prices has been a politically sensitive matter in India as it potentially affects the middle class voting pattern.

\section{* Rural heating}

Predominantly in Europe and rural parts of many countries, LPG can provide an alternative to electric heating, heating oil or kerosene. LPG is most often used in areas that do not have direct access to piped natural gas. The LPG is used to heat the water that travels through a closed pipe system to radiators. The radiators are positioned all the way through the home. This technology has allowed LPG to be used not just as fuel for heating and cooking, but also for decentralized generation of electricity.

\section{* Motor fuel}

Autogas is the common name for liquefied petroleum gas (LPG) when it is uses as a fuel in internal combustion engines in vehicles as well as in stationary applications such as generators. Its advantage is that it is non-toxic, noncorrosive. LPG has a lower energy density per litre than petrol or fuel-oil, so the equivalent fuel consumption is higher. Many governments impose less tax on LPG than on petrol or fuel-oil.

\section{* Conversion to gasoline}

LPG can be converted into alkylate which is a premium gasoline blending stock because it has exceptional antiknock properties and gives clean burning.

\section{* Refrigeration}

LPG is instrumental in providing off-thegrid refrigeration, usually by means of a gas absorption refrigerator.

\section{RESEARCH METHODOLOGY}

Research methodology is a way to systematically solve the research problems. It may be understood as a science of studying how research is done scientifically. The research methodology adopted for the present study has been systematic and was done in accordance to the objectives set, which has been discussed in earlier pages.

\section{SAMPLE DESIGN}

It is not possible to collect information from the entire customers, who are all using HP LPG. Therefore, Judgment sampling method is applied. Researcher uses his/her judgment in selecting the units from the population for study based on the population's parameters.

\section{SAMPLE SIZE}

In this study the sample size is 351 , who were using HP LPG in Theni district. 
Sample Size

\begin{tabular}{|c|l|c|}
\hline S.No & \multicolumn{1}{|c|}{ Places } & Sample Size \\
\hline 1. & Theni & 85 \\
\hline 2. & Periyakulam & 46 \\
\hline 3. & Uttampalyam & 36 \\
\hline 4. & Cumbum & 24 \\
\hline 5. & Bodinayakanur & 55 \\
\hline 6. & Chinnamanur & 20 \\
\hline 7. & Kadamalaikundu & 20 \\
\hline 8. & Devadanapatti & $\mathbf{3 5 1}$ \\
\hline Total & \\
\hline & &
\end{tabular}

\section{SUMMARY OF FINDING}

Findings are the means from interpretation and generalization which provides suggestions and after valuable conclusion. In this regard the researcher consolidates the findings of her research under the study.

\section{SIMPLE PERCENTAGE ANALYSIS}

The study reveals the following:

* Majority of the respondents $(65.81 \%)$ are Female customers.

* Majority of the respondents $(50.43 \%)$ belongs to the age group of 31-40 yrs.

* Majority of the respondents (29.91\%) having the school level education.

* Majority of the respondents $(26.78 \%)$ are belongs to the private employee.

* Majority of the respondents (39.89\%) are belongs to the monthly income group of Rs.5000Rs. 10000 .

* Majority of the respondents $(82.63 \%)$ are married.

* Majority of the respondents $(82.05 \%)$ are belongs to nuclear family.

* Majority of the respondents (48.43\%) are belongs to 2-4 members in their family.

* Majority of the respondents (38.75) are used Kerosene before purchase of LPG.

* Majority of the respondents $(63.53 \%)$ are having the reason to purchase LPG is because of Easier \& Quicker to cook.

* Majority of the respondents $(85.47 \%)$ are using $14.2 \mathrm{~kg}$ capacity of gas cylinder.

* Majority of the respondence (54.70\%) are using LPG 1-2 hours/day for cooking purpose.

* Majority of the respondence $(52.99 \%)$ are refill their LPG cylinder between 31-60 days.

* Majority of the respondence (47.29\%) are booked their LPG cylinder through Phone.

\section{CORRELATION ANALYSIS}

\section{a)Personal factor and Study factor}

* There is very strong positive Relationship between the Family members and LPG Used hours per day

* There is strong positive Relationship between the Family members and Refill gap between 2 cylinders

* There is weak positive Relationship ship between the Family members and reason for purchasing LPG

* There is a positive Relationship between Age group and Gas booking method

* There is a positive Relationship between Monthly Income and reason for purchasing LPG

* There is a weak Relationship between Age group and reason for Purchasing LPG

b) Study factor and Study factor

* There is a no Relationship between the Fuel used before LPG and reason for purchasing LPG

* There is Very strong positive Relationship between Fuel Refill gap two cylinders and used hours per day

* There is a positive Relationship between Awareness factor and reason for purchasing LPG

There is a strong positive Relationship ship between Gas booking method and Delivery time

There is negative relationship ship between Extra amount charges by the delivery man and Delivery time

\section{GARRETT'S RANKING TECHNIQUES}

\section{Most important problem faced by the customers}

Respondents have ranked first and second to the "Customer care centers are available for listening complains and Irregularity of increasing price and Gas cylinder and accessories are checked at the time of installation". These two factors are most important problem faced by the customer.

\section{LIKERT SCALING TECHNIQUES}

\section{Most important factor satisfied by the customers}

Respondents highly satisfied on "Quality \& Quantity of the LPG and Delivery time of LPG Gas after booking". These two factors are highly satisfied by the customer. 


\section{ANALYSIS OF VARIANCE}

There is a major difference between gender and Respondents opinion towards problem faced by the customers in all the above cases. Hence the two groups of variables are dependant with each other.

There is no major difference between Age and Respondents opinion towards problem faced by the customers in all the above ten cases. Hence the two groups of variables are independents.

\section{CONCLUSION}

"The customer is always right" is a famous business slogan. The findings of the study makes clear that the customers having faced the irregularity of price increase and delayed supply of LPG gas cylinders. It is suggested that the HP gas company should take some necessary action to improve their service quality by the way they can introduce some more dealers and provide service to the customers. The company needs to improve in customer care area, proper communication while booking and delivery through short message service (SMS).

\section{REFERENCE}

1. Purvin \& Gertz (2013) "World LPG Market Outlook" 'NGL Publications, Seminars and Workshops'

2. Babasab Patil (2012), "Customer satisfaction on bharat gas agencies in Coimbatore", 'Bharat book bureau presents UK consumer satisfaction index'

3. Melody Meckeown (2005), "Competition commission Domestic Bulk LPG" 'www.competitioncommission.org.uk/.../cc_lpg_presentation_orc_cha nges'

4. Antonette D'Sa and K.V.Narasimha Murthy (2000), "Report on the use of LPG as a domestic cooking fuel option in India" 'International Energy Initiative, Bangalore' Volume 8, Issue 3, September 2004'

5. C. R. Kothari, "Research Methodology: Methods and Techniques", $2^{\text {nd }}$ Edition, New Age International (P) Ltd., New Delhi, 2006.

6. S.P. Gupta, "Statistical Methods", Sultan Chand and Sons Publications, $38^{\text {th }}$ Edition, 2009.

7. www.google.com

8. www.wikipedia.com

9. www.researchgate.net 